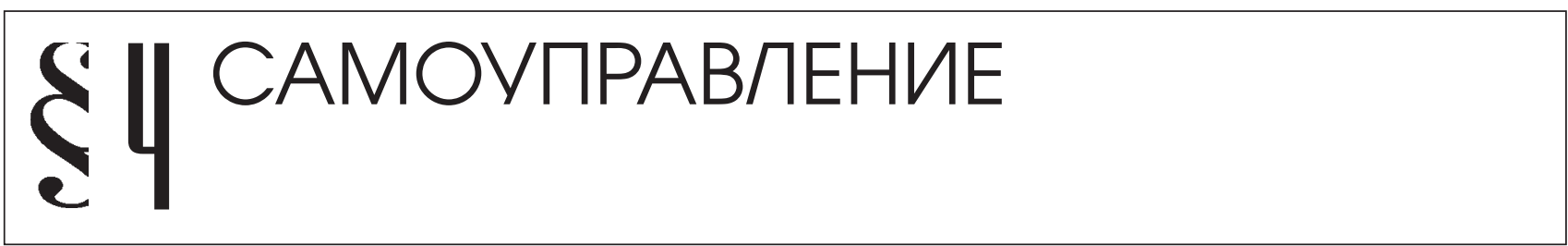

Т.И. Минковская

\title{
ПОЛНОМОЧИЯ ОРГАНОВ МЕСТНОГО САМОУПРАВЛЕНИЯ В ОБЛАСТИ ИСПОЛЬЗОВАНИЯ И ОХРАНЫ ЗЕМЛИ
}

Аннотация: На основе анализа действующего законодательства, а также законодательства РСФСР, рассмотрены вопросы охраны земель на территории муниципальных образований, а также полномочия органов местного самоуправления в этой сфере. Конституцчия РФ, признавая и защчищая равным образом муниципальную и иные формы собственности, закрепляет положение о том, что земля и другие природные ресурсы могут находиться в муниципальной собственности. Таким образом, в соответствии с действующим законодательством органы местного самоуправления имеют широкие и на наш взгляд, достаточные полномочия для организации эффективного контроля в области использования и охраны земли.

Ключевые слова: Юриспруденция, полномочия, самоуправление, охрана, использование, земля, законодательство, муниципалитет, собственность, кодекс

онституция РФ, признавая и защищая равным образом муниципальную и иные формы собственности, закрепляет положение о том, что земля и другие природные ресурсы могут находиться в муниципальной собственности. Проблема эффективного использования и охраны земель муниципальных фондов исторически решалась сложно, особенно в условиях рыночной экономики. Как справедливо полагает Л.В. Алиева, «попытки советского правительства упорядочить земельные отношения на селе... в период 1922 - 1927 гг. успехом не увенчались, поскольку благие начинания в результате их практического применения на местах сталкивались с многочисленными трудностями. В результате к 1928 г. земельные проблемы так и не были решены» [9]. В советское время неоднократно принимались партийно-правительственные постановления по борьбе с «разбазариванием» земель. В современных условиях проблема сохраняет актуальность.

В соответствии с Земельным кодексом РФ (далее-ЗК РФ) муниципальная собственность на земельные участки возникает:

- с признанием таковыми федеральными законами и принятыми в соответствии с ними законами субъектов Федерации;

- при разграничении государственной собственности на землю;

- при приобретении по основаниям, установленным ГК РФ [1].

В муниципальной собственности могут находиться не предоставленные в частную собственность земельные участки по основаниям, предусмотренным Федеральным законом «О разграничении государственной собственности на землю» [2]. 


\section{Тренды и управление - №1(1)• 2013}

При решении этого вопроса необходимо учитывать, что в собственность муниципальных образований для обеспечения их развития могут безвозмездно передаваться земли, находящиеся в государственной собственности, в том числе за пределами границ муниципальных образований.

Статья 11 ЗК РФ содержит открытый перечень полномочий органов местного самоуправления в области земельных отношений:

- резервирование земель, изъятие, в том числе путем выкупа, земельных участков для муниципальных нужд;

- установление с учетом требований законодательства РФ правил землепользования и застройки территорий городских и сельских поселений, муниципальных образований;

- разработка и реализация местных программ использования и охраны земель;

- иные полномочия на решение вопросов местного значения в области использования и охраны земель.

Кроме того органы местного самоуправления управляют и распоряжаются земельными участками, находящимися в муниципальной собственности

Таким образом, органы местного самоуправления имеют широкий круг полномочий в области использования земли, законодательно ограниченный лишь отнесением их к вопросам местного значения.

Для реализации, предусмотренных ЗК РФ полномочий органы местного самоуправления в сфере использования земли занимаются:

- правовым регулированием (в пределах своих полномочий) общественных отношений, связанных с использованием земли;

- планированием использования земель;

- формированием в структуре местной администрации органов (структурных подразделений), осуществляющих управление и распоряжение земельными участками, находящимися в муниципальной собственности;
- владением, пользованием и распоряжением земельными участками, находящимися в муниципальной собственности;

- вопросами землеустройства, установления платы за землю, а также муниципального земельного контроля.

Органы местного самоуправления, решая вопросы своего ведения в области земельных отношений, в пределах своих полномочий могут согласно ЗК РФ издавать акты, содержащие нормы земельного права (ст. 2).

В соответствии с Федеральным законом «Об общих принципах организации местного самоуправления в Российской Федерации» [3], Градостроительным кодексом РФ [4] органы местного самоуправления утверждают генеральные планы поселений схемы территориального планирования муниципального района, правила землепользования и застройки и т. д. Они также вправе разрабатывать и реализовывать местные программы использования и охраны земель. При этом они обязаны обеспечить возможность участия граждан и общественных организаций (объединений) в решении вопросов, касающихся их прав на землю.

Планирование использования земель осуществляется органами местного самоуправления, прежде всего посредством утверждения генеральных планов поселения, городского округа, схем территориального планирования муниципального района, подготовленной на основе указанных документов документации по планировке территории, а также ведения информационной системы обеспечения градостроительной деятельности, осуществляемой на территории муниципального образования, резервирования земельных участков для муниципальных нужд и т. д.

На территории городских и сельских поселений могут устанавливаться территориальные зоны различных видов: жилые, производственные, рекреационные, сельскохозяйственного использования и др. 
Планирование и организация рационального использования земель проводятся в целях совершенствования распределения земель в соответствии с перспективами развития экономики, улучшения организации территорий и определения иных направлений рационального использования земель в муниципальных образованиях.

Планирование и организация рационального использования земель и их охраны включают в себя следующие основные виды работ:

- природно-сельскохозяйственное районирование земель;

- определение земель, в границах которых гражданам и юридическим лицам могут быть предоставлены земельные участки;

- определение земель, включаемых в специальные земельные фонды;

- определение земель, отнесенных к категориям и видам, установленным законодательством РФ.

Управляя и распоряжаясь муниципальной землей, органы местного самоуправления предоставляют муниципальные земельные участки в собственность граждан и юридических лиц, за исключением земельных участков, которые в соответствии с ЗК РФ, федеральными законами не могут находиться в частной собственности. Земельные участки, находящиеся в муниципальной собственности могут предоставляться в аренду.

ЗК РФ закрепляет соответствующие полномочия органов местного самоуправления в сфере земельных отношений, устанавливая:

- порядок предоставления земельных участков для строительства из земель, находящихся в муниципальной собственности;

- особенности предоставления земельных участков для их комплексного освоения в целях жилищного строительства из земель, находящихся в муниципальной собственности;

- порядок организации и проведения аукционов по продаже земельных участков из земель, находящихся в муниципальной собственности, либо права на заключение договоров аренды земельных участков из земель, находящихся в муниципальной собственности, для жилищного строительства и т. д.

ЗК РФ обязывает органы местного самоуправления городских или сельских поселений информировать население о возможном или предстоящем предоставлении земельных участков для строительства. Граждане, общественные организации (объединения), религиозные организации и органы территориального общественного самоуправления имеют право участвовать в решении вопросов, затрагивающих интересы населения, религиозных организаций и связанных с изъятием, в том числе путем выкупа, земельных участков для муниципальных нужд и предоставлением этих земельных участков для строительства. Органы местного самоуправления, субъекты хозяйственной и иной деятельности обязаны обеспечить возможность такого участия в порядке и в формах, которые установлены законодательством.

В соответствии с ЗК РФ предельные (максимальные и минимальные) размеры земельных участков, предоставляемых гражданам в собственность из находящихся в муниципальной собственности земель, для ведения личного подсобного хозяйства и индивидуального жилищного строительства устанавливаются нормативными правовыми актами органов местного самоуправления. Максимальные размеры земельных участков, предоставляемых гражданам в собственность бесплатно для указанных целей, устанавливаются: нормативными правовыми актами органов местного самоуправления.

Предоставление гражданам и юридическим лицам земельных участков осуществляется на основании решения органа местного самоуправления, обладающего правом предоставления соответствующих земельных участ- 


\section{Тренды и управление - №1(1) • 2013}

ков (в соответствии с уставом муниципального образования), в пределах своей компетенции и в соответствии с Земельным кодексом.

Земельный кодекс упростил порядок приватизации земельных участков, в том числе находящихся в муниципальной собственности. Если гражданин или юридическое лицо пожелают приватизировать ранее предоставленные им земельные участки, то орган местного самоуправления обязан в двухнедельный срок принять решение о предоставлении земельного участка в собственность гражданина или юридического лица.

Земельный кодекс определяет порядок предоставления земельных участков, находящихся в муниципальной собственности, для строительства (торги, конкурсы, аукционы). Предметом торгов может быть земельный участок с установленными границами или право на заключение аренды такого земельного участка. Предоставление земельных участков для строительства также может быть осуществлено с предварительным согласованием места размещения объекта. Орган местного самоуправления обеспечивает определение вариантов размещения объекта и информирование населения о возможном или предстоящем предоставлении земельного участка. Результаты выбора участка и предварительное согласование места размещения объекта оформляется актом о выборе участка. Этот акт является основанием для последующего принятия органом местного самоуправления решения о предоставлении земельного участка.

ЗК РФ также определяет порядок предоставления гражданам земельных участков в собственность (за плату или бесплатно) либо в аренду для целей, не связанных со строительством. Органы местного самоуправления обязаны обеспечить управление и распоряжение земельными участками, которые находятся в собственности и (или) в ведении муниципального образования, на принципах эффективно- сти, справедливости, публичности, открытости и прозрачности процедур предоставления таких участков. Для этого устанавливаются процедуры и критерии предоставления таких участков, в том числе порядок рассмотрения заявок и принятия решений; на управление и распоряжение земельными участками и иной недвижимостью уполномочивается специальный орган; информация о земельных участках заблаговременно публикуется.

ЗК РФ кодекс допускает предоставление в постоянное (бессрочное) пользование земельных участков муниципальным учреждениям, органам местного самоуправления и др. Вместе с тем гражданам участки не могут предоставляться в постоянное (бессрочное) пользование. Однако право постоянного (бессрочного) пользования находящимися в муниципальной собственности земельными участками, которое возникло у граждан или юридических лиц до введения в действие Земельного кодекса 1991 г. [5], сохраняется. При этом субъекты данного права не вправе распоряжаться этими земельными участками. Кодекс разрешает гражданам, обладающим земельными участками на праве постоянного (бессрочного) пользования, приобретать их в собственность. Права на земельные участки удостоверяются в соответствии с Федеральным законом «О государственной регистрации прав на недвижимое имущество и сделок с ним» [6].

ЗК РФ предусматривает возможность принудительного прекращения прав на земельный участок лиц, не являющихся его собственниками, ввиду ненадлежащего использования участка и определяет права органов местного самоуправления как участников данного процесса. Так, орган местного самоуправления после получения соответствующих материалов от исполнительного органа государственной власти по осуществлению государственного земельного контроля направляет в суд заявление о 
прекращении права на земельный участок, а по истечении десятидневного срока с момента принятия решения суда о прекращении права на земельный участок направляет заявление о государственной регистрации прекращения права на земельный участок с приложением акта в орган государственной регистрации прав на недвижимое имущество и сделок с ним.

ГК РФ и ЗК РФ определяют условия и порядок изъятия, в том числе путем выкупа, земельных участков для муниципальных нужд. Изъятие земельных участков для муниципальных нужд осуществляется в исключительных случаях.

В соответствии с Федеральным законом от 30 апреля 1999 г. «О гарантиях прав коренных малочисленных народов Российской Федерации» органы местного самоуправления осуществляют контроль за отводом, использованием и охраной лицами, относящимися к малочисленным народам, земель, необходимых для ведения традиционного образа жизни и занятия традиционными промыслами малочисленных народов [7]. Лица, относящиеся к малочисленным народам, безвозмездно владеют и пользуются в местах традиционного проживания и хозяйственной деятельности малочисленных народов землями различных категорий, необходимыми для осуществления их традиционного хозяйствования и занятия традиционными промыслами, и общераспространенными полезными ископаемыми.

Органы местного самоуправления в соответствии с Конституцией РФ могут наделяться законом отдельными государственными полномочиями в области осуществления деятельности по ведению Государственного земельного кадастра с передачей необходимых для их осуществления материальных и финансовых средств.
Включение в Государственный земельный кадастр дополнительных сведений, не установленных Российской Федерацией и ее субъектами, является расходным обязательством муниципальных образований.

В соответствии с Федеральным законом 2001 г. «О землеустройстве» решение органов местного самоуправления является основанием для проведения землеустройства [8].

Таким образом, в соответствии с действующим законодательством органы местного самоуправления имеют широкие и на наш взгляд, достаточные полномочия для организации эффективного контроля в области использования и охраны земли.

\section{Библиография:}

1. Земельный кодекс Российской Федерации от 25.10.2001 (ред. от 28.07.2012) N 136-Ф3.

2. Федеральный закон от 17.07.2001 г. N 101Ф3 (ред. от 03.06.2006 г.) «О разграничении государственной собственности на землю».

3. Федеральный закон от 06.10.2003 N 131-Ф3 (ред. от 16.10.2012) «Об общих принципах организации местного самоуправления в Российской Федерации».

4. Градостроительный кодекс Российской Федерации от 29.12.2004 (ред. от 12.11.2012) N 190-Ф3.

5. Земельный кодекс РСФСР от 25 апреля 1991 г. (ред от 01.04. 1994 г. )// Ведомости СНД и ВС РСФСР. 30.05.1991. N 22. Ст. 768.

6. Федеральный закон от 21.07.1997 N 122-Ф3 (ред. от 28.07.2012 г.) «О государственной регистрации прав на недвижимое имущество и сделок с ним».

7. Федеральный закон от 30.04.1999 N 82Ф3 (ред. от 05.04.2009) «О гарантиях прав коренных малочисленных народов Российской Федерации». 


\section{Тренды и управление - №1(1) • 2013}

8. Федеральный закон от 18.06.2001 г. N 78-Ф3 (ред. от 18.07.2011 г.) «О землеустройстве».

9. Алиева Л.В. Реализация Земельного кодекca РСФСР 1922 г. в контексте эволюции крестьянской поземельной общины (на материале Псковской губернии)// Псков. 2006. №24. C. 147-153.

\section{References (transliteration):}

1. Alieva L.V. Realizatsiya Zemel'nogo kodeksa RSFSR 1922 g. v kontekste evolyutsii krest'yanskoy pozemel'noy obshchiny (na materiale Pskovskoy gubernii)// Pskov. 2006. №24. S. 147-153. 